\title{
Inheritance and Teaching Research of Folk Music in Contemporary Education
}

\author{
Qiaowei Li, Tianhui Zhang \\ Academy of Music, Hengyang Normal University, Hengyang City, \\ Hunan Province, 421002, China
}

\begin{abstract}
National music is the treasure of national culture in China, which also is one of the spiritual motive forces of Chinese nation's continual development. As an important field of national music culture, school education must seek a new orientation in the music education of current multicultural world. China has made a lot of music teaching reform in the past many years, with having achieved some success in all aspects. But how to inherit and develop the national music culture in the contemporary music education is still a problem that can not be ignored. Based on the author 's teaching experience, this paper firstly analyzes the problems in the inheritance and education of national music culture, and then it puts forward the teaching strategies of inheriting the national music culture in the college music teaching.

Key words: Contemporary education; Folk music; Inheritance; Teaching
\end{abstract}

\section{Introduction}

Today's society, is an era of knowledge economy when spiritual culture is as the first resource, attaches great importance to human health and full development of creativity. However, the characteristics of national culture and multicultural concepts are the inexhaustible sources of the developments of individual and social creativity[1]. Therefore, we should respect, protect and inherit the national culture. Paying attention to the development of our own cultural characteristics and seeking cultural resource of our country become the basic national policies for the people of all nationalities in today's world to seek development and 
promote development. In this context, as one of the important resources of national culture, national music culture should be well inherited and developed.

\section{The Problems in the Inheritance Education of the National Musical Culture in Colleges and Universities}

\subsection{National music teaching method is single}

At present, most of the music teaching modes in colleges and universities is based on the traditional teaching mode of listening to music and then imitating music. To a certain extent, this traditional teaching method often shows a single teaching mode, means not new, lack of innovation, and easy to make teaching atmosphere too boring, so that students lose their enthusiasm for learning. Over time, students will feel it more difficult to learn the national music of skill-intensive courses. If still using the traditional means of teaching, it will make students lose interest in learning and increase the difficulty of understanding of folk music. At the same time, for the teachers, the teaching means of a single, will make the teaching process more difficult,so that the true purpose of national music heritage can not be achieved[2].

\subsection{Students' understanding of the culture of the national music is not sufficient}

Current college students generally like contemporary music, and they love to listen to pop music and online music, having little contact with the national music. Ethnic music courses are not same as other basic theory courses, which need to master a lot of music knowledge and music culture, But most students did not have a systematic understanding of the process in the study before the music, this problem is very detrimental to national music teaching[3]. To different stages in practice teaching and learning of students according to different situations of the systematic analysis, teachers should put forward different teaching methods and measures, in accordance with their aptitude to fundamentally improve the students' comprehensive quality and ability of learning music.

\subsection{Resources of national music teachers are weak}

At present, resources of teachers in the national music specialty are weak, lacking in the talents of high degree of specialization and high level of teaching in national music education and teaching. It can not update the teaching concepts in time for music teachers having little chance of learning. All kinds of problems have seriously hindered the development and innovation of national music teaching. The lack of teachers has brought some difficulties to the cultural heritage. So to focus on solving the problem of teachers in the next music teaching work can really improve the quality of national music teaching. 


\subsection{The content of the teaching of ethnic music is relatively simple}

At present, the major folk music to learn in the teaching of the appreciation of the national music tracks in colleges and universities are all a small number of tracks that teachers are familiar with. There is no deep excavation of teaching resources, with the idea that it is enough to just let the students understand and master to the primary level, so leading to the lack of new ideas in teaching. This cycle of repeated practice exercises will make the students can not get the spirit of learning and it difficult to be active for classroom atmosphere, and has also caused a certain obstacle in mastering the essence of music and music culture. In addition, the content of the national music teaching is not closely related to the historical and cultural value of the music itself[4]. The whole process of teaching can not really achieve the integration of music history and culture, and the cultivation of students' creativity is limited. This limits the students' independent thinking mode and also is not conducive to the inheritance of national music culture.

\section{Teaching Strategies of Inheriting National Music Culture in Music Teaching in Colleges and Universities}

\subsection{The use of multimedia in teaching the penetration of national music culture}

In order to improve the music appreciation and creative ability of college students, the teachers should devote themselves to how to carry forward the national music culture better and do a better job in teaching music in colleges and universities. In modern teaching, the application of multimedia can be said to be everywhere, of course, in the courses of national music teaching can also be introduced into the classroom, so as to enrich the classroom teaching content. In addition, some national music learning lectures can also be given to students to learn to improve the abilities of students. It can give students a more intuitive feeling and make it easier to learn the history of national music culture with a multimedia presentation[5].

\subsection{Focus on collaborative learning to promote the national music culture}

With students in the national music appreciation, teachers can use different teaching forms and teaching methods to express different musical styles, in order to attract students to the teaching interest and enthusiasm. Such as by explaining the diagram, interpretation of the different national music melody ways to deepen students' understanding of music, passing the charm and value of the music itself and making a meaningful positive response to national music according to their own preferences, improving the appreciation of the national music ability, and enhancing the interaction between teachers and students collaboration, thus they can develop the aesthetic enjoyment of national music and get more knowledge 
about folk music. Through the expression of folk music and communication in creative ideas and so on to develop students' learning ability and musical creativity, and promote positive and effective concept's development of national music, to promote a deeper understanding of national music learning.

\subsection{Job placement to pay attention to gradient}

Level of university students in the music is uneven, and the music comprehend ability is also very different, so teachers should take full account of those in job placement. For the national music culture, the degree of penetration varies from person to person, the difficulty of the repertoire of the work should be extended to make the acceptance of good students in the operation can be further improved and developed, for students who learn the national music more difficultly, allowing them to carry out basic exercises to consolidate the good music foundation[6]. Extracurricular, teachers should encourage students to get in touch with the culture of various nationalities and travel to many places to enjoy the scenery of different regions and appreciate the different music in different ethnic areas at the same time, and to deepen the understanding and understanding of the national music culture. Only in this way can we make the music comprehension ability of the whole class be improved effectively, and the teaching effect will be better displayed, and then we can achieve the goal of music learning better.

\subsection{The introduction of collective music teaching in the show}

In the study of folk music it needs one link to show, that is, students show the process of learning outcomes. In the preparation of this session, we should pay attention to the communication between students as well as teachers and students, the discussion allows students to grasp the content of teaching better, and practical performance can exercise the students music ability better. Conduct a comprehensive understanding of the origin and development of national music in the preparation process, so that students will be more interested in listening and performing folk music[7]. In observing the performance of other students, students can find the advantages and disadvantages of themselves and others. In addition, the process of the collective display is one way to mobilize the atmosphere of the classes, to increase students' curiosity of knowledge and attract the attention of students, so that each student can continue to enhance himself and feel the culture, and to understand and carry forward the national music culture.

\subsection{Collective commentary to promote the cultural heritage of national music}

The evaluation in national music classes is a beneficial to the communication link that each one airs his own views. Teachers can first make evaluation about students' classroom performance of learning national music, and then let students comment, they can comment on their own or others and express any view. Teachers do not casually interrupt them in the process to allow students to express what they want completely and then comment. In the comment process 
teachers can let students have active thinking and analysis of national music culture to use their own way to digest and absorb, and cultivate students' good ability to analyze and solve problems. More importantly, students can learn more knowledge and improve their ability to lay the future roads for music in this process.

\section{Conclusion}

How to conduct demonstrative teaching of ethnic music, improve the effective learning efficiency of classroom, improve the positive interaction between students and teachers, impart important content of music knowledge, transmit and advocate music culture and so on, are all the problems to be considered in the teaching process. Throughout the teaching process to firmly grasp the student's attention and teach students in accordance with their aptitude, it is necessary not only to follow the contents of the syllabus, but also to make use of novel content in the teaching to enrich the classes. Only by constantly summing up experience in practice, can we make continuous progress in curriculum design, can we improve the teaching efficiency of music course more effectively, can we make the students better grasp the content of teaching, can we cultivate more talents for China's music industry and contribute to the deepening of educational reform.

\section{Acknowledgement}

The research was supported by the following items:

(1) Project of Hunan Province social science achievement evaluation committee: The Real Dilemma of Hunan Flower Drum Song and Its Innovation and Development(Number XSPYBZZ002).

(2) Project of Hengyang City Social Science Fund: The Inheritance Strategies of Hengyang Music Culture in Local College Music Education(Number 2015D121).

(3) Project of Hengyang City Social Science Fund: Hengyang City music culture from the perspective of Ecotourism - A Case Study based on Hengzhou Flower Drum Song(Number 2015D083).

\section{References}

[1] Wang Ruigang. University music teaching and the cultural heritage of national music. Heilongjiang Science, (11), pp.82-87, 2015.

[2] Liu Rongwei. On the university music teaching and cultural heritage of national music research. Music time and space, (19), pp.51-52, 2015.

[3] Shi Liming.Discussion on Music Teaching and Inheritance of National Music Culture in Colleges and Universities .Journal of the Yellow River, (04), pp.63-65, 2015. 
[4] Zhao Jing. On college music teaching and cultural heritage of national music. Music and time, (21), pp.159-160, 2014.

[5] Zou Lixia. University music teaching and cultural heritage of national music. Journal of Hangzhou Institute of Commerce, (01), pp.70-72, 2004.

[6] Chen Qishe. On the Teaching of Music and the Inheritance of Folk Music. People's Music, (04), pp.29-32, 2000.

[7] Chen Qishi. The Inheritance of Folk Music and the Teaching of Music in Normal Colleges. Symphony. Journal of Xi'an Conservatory of Music, (04), pp.22-26, 1999. 